\title{
АРХЕОЛОГИЯ
}

DOI: https://doi.org/10.15688/jvolsu4.2018.4.1

UDC 572

Submitted: 19.03 .2018

LBC 63.3

Accepted: 07.06.2018

\section{THE MATERIALS FOR CRANIOLOGY OF THE NORTHERN SAMODIANS ${ }^{1}$}

\author{
Anatoliy N. Bagashev \\ Tyumen Scientific Centre, Siberian Branch of Russian Academy of Sciences, Tyumen, Russian Federation
}

\section{Sergey M. Slepchenko}

Tyumen Scientific Centre, Siberian Branch of Russian Academy of Sciences, Tyumen, Russian Federation; Ugra Laboratory for Archaeology and Ethnology, Surgut State University, Surgut, Russian Federation

\section{Oleg V. Kardash}

Ugra Laboratory for Archaeology and Ethnology, Surgut State University, Surgut, Russian Federation

\begin{abstract}
A small sample of paleoanthropological materials from the burial grounds Buchta Nakhodka 2 and Yumadoto 1 in the Yamal Peninsula (Yamal district of Yamalo-Nenets Autonomous Okrug of Tyumen Region) has been studied in order to specify the nature of intra-group and inter-population variability. The morphological features of the skulls indicate their belonging to the eastern Mongoloid anthropological formation, but in terms of the nasal bridge structure, they at the same time tend to the western Caucasoid population. According to the results of multidimensional statistics, despite a high individual variability typical of the modern species of Homo sapiens, the range of variability observed in the materials from the burial grounds Buchta Nakhodka 2 and Yumadoto 1 is not beyond the scope of the inter-group variability typical of the Northern Samodians. A more representative sample of this ethnic group has been formed on this basis, which is taxonomically included in the Yamalo-Enisey group of populations of the West Siberian anthropological formation.

$\infty \quad$ Authors' contribution: A.N. Bagashev and S.M. Slepchenko have made measurements of skulls, analyzed the obtained data and have written the paper; O.V. Kardash has carried out archaeological excavations of the burial ground Bukhta Nakhodka 2 and has co-written the paper.

Key words: anthropology, population, systematics, taxonomy, Northern Eurasia, Yamal Peninsula, the Northern Samodians, the Nenets, the Kets.

Citation. Bagashev A.N., Slepchenko S.M., Kardash O.V. The Materials for Craniology of the Northern Samodians. Vestnik Volgogradskogo gosudarstvennogo universiteta. Seriya 4, Istoriya. Regionovedenie. Mezhdunarodnye otnosheniya [Science Journal of Volgograd State University. History. Area Studies. International Relations], 2018, vol. 23, no. 4, pp. 6-14. DOI: https://doi.org/10.15688/jvolsu4.2018.4.1

\section{МАТЕРИАЛЫ К КРАНИОЛОГИИ СЕВЕРНЫХ САМОДИЙЦЕВ ${ }^{1}$}

\section{Анатолий Николаевич Багашев}

\author{
Тюменский научный центр, Сибирское отделение РАН, г. Тюмень, Российская Федерация
}




\title{
Сергей Михайлович Слепченко
}

Тюменский научный центр, Сибирское отделение РАН, г. Тюмень, Российская Федерация; Югорская лаборатория археологии и этнологии, Сургутский государственный университет, г. Сургут, Российская Федерация

\section{Олег Викторович Кардаш}

Югорская лаборатория археологии и этнологии, Сургутский государственный университет, г. Сургут, Российская Федерация

\begin{abstract}
Аннотация. Для конкретизации характера внутригрупповой и межпопуляционной изменчивости исследована небольшая выборка палеоантропологических материалов из могильников Бухта Находка 2 и Юмадото 1 на Ямале (Ямальский район Ямало-Ненецкого автономного округа Тюменской области). Особенности морфологического облика черепов свидетельствуют о принадлежности их к восточной монголоидной антропологической формации, однако по строению переносья они тяготеют одновременно к западному европеоидному населению. По результатам многомерной статистики вытекает, что, несмотря на высокую индивидуальную изменчивость, характерную для современного вида Ноmo sapiens sapiens, размах изменчивости, отмеченный по материалам из могильников Бухта Находка 2 и Юмадото, не выходит за пределы межгрупповой изменчивости, свойственной северным самодийцам. На этом основании сформирована более репрезентативная выборка по этой этнической группе, которая в таксономическом отношении включена в ямало-енисейскую группу популяций западносибирской антропологической формации.

Вклад авторов: Багашев А.Н. Проведение измерений черепов, анализ полученных данных, написание статьи. Слепченко С.М. Проведение измерений черепов, анализ полученных данных, написание статьи. Кардаш О.В. Проведение археологических раскопок могильника Бухта Находка 2, написание статьи.

Ключевые слова: антропология, популяция, систематика, таксономия, Северная Евразия, полуостров Ямал, северные самодийцы, ненцы, кеты.
\end{abstract}

Цитирование. Багашев А. Н., Слепченко С. М., Кардаш О. В. Материалы к краниологии северных самодийцев // Вестник Волгоградского государственного университета. Серия 4, История. Регионоведение. Международные отношения. - 2018. - Т. 23, № 4. - С. 6-14. (на англ.). - DOI: https://doi.org/10.15688/jvolsu4.2018.4.1

\section{Introduction}

Contemporary aboriginal population of Northern Eurasia belongs to various ethnolinguistic groups (Samoyeds, Finno-Ugrians, Turks, Kets, Paleo-Asiatics), whose traditional cultures are represented by various economic and cultural types of appropriating and producing economies. Just as their cultures and natural and climatic habitat conditions are greatly diverse, so are the anthropological differences between them, which generally suggests different ways of their ethnogenesis. Anthropology clarifies only one side of the origin of tribes - history of formation of their physical appearance features, in the reconstruction of which the taxonomic classification of anthropological communities holds an important place, as it reflects common and different elements in the genesis and historical destinies of populations.

Atribution of some peoples of Northern Eurasia is a matter of debate in the modern taxonomic configuration. This is true, in particular, for the Northern Samoyed peoples (Nenets, Enets and Nganasan) and the Ket people, which is caused by a lack of available materials. Introduction of new anthropological data on the physical appearance features of the inhabitants of West Siberian subarctic regions allows us to clarify the limits of individual and inter-group variability typical to them. This article considers new craniological findings obtained from a study of the archaeological sites of Buchta Nakhodka 2 and Yumadoto 1 in the Yamal Peninsula in order to specify the population structure and systematics of the indigenous peoples of the North.

\section{Archaeological context}

Soil burial grounds in the tundra zone of the Far North of Western Siberia (the Yamal Peninsula) have not been known till present. Only single graves were found. During exploration works in the southern part of the Yamal Peninsula in 2012 the first medieval burial complex, the Buchta Nakhodka 2 burial ground, was discovered. The first reconnaissance study of the 
archaeological site took place in the summer of $2016[14 ; 17]$.

The Buchta Nakhodka 2 burial ground is located on the western shore of an unnamed lake near the coast of the Nakhodka Bay, at the Gulf of $\mathrm{Ob}$ of the Kara Sea, $255 \mathrm{~km}$ northeast from Salekhard, and $75 \mathrm{~km}$ northeast from Yar Sale dwelling in Yamalsky District of Yamalo-Nenents Autonomus Okrug.

Archaeological results of the archaeological site investigation show that the object under study has several unique features.

Firstly, at the territory of the burial ground there were graves dating back to different time periods. The first burial group refers to the Zelenogorsk archaeological culture dating back to the middle $6^{\text {th }}-$ middle $7^{\text {th }}$ centuries. The second group includes burials of the $12^{\text {th }}-13^{\text {th }}$ centuries that were left by dwellers from the nearest synchronous fortified settlement which the contemporary local people, the Nenets, identify with the folklore and mythological population "sikhirtya" [13].

Secondly, all the known medieval soil burial grounds in the North of Western Siberia do not have direct connection to long-term settlements. The Buchta Nakhodka 2 burial ground appears to be the first burial complex that was left by the population who had lived near the Nakhodka Bay which was proved during the archaeological excavations.
Thirdly, the Buchta Nakhodka 2 burial ground has two special features of the burial rite. In graves of the $12^{\text {th }}-13^{\text {th }}$ centuries individuals were laid on the left side of the body, in a crooked position, which is unusual for the North of Western Siberia and had not been recorded for other medieval burial grounds before [18]. Burials in such a position are more common for the population in the South Siberia. The second feature is inhumation (burial in the ground) of the deceased which is characteristic for all medieval burial grounds in the Taiga zone of the North of Western Siberia. Modern indigenous people (the Nenets) and the near-modern population of the tundra, who have lived in the Yamal Peninsula, have been practicing for at least the last 200 years above-ground burials in special boxes - halmers.

Anthropological materials from the burial ground of Yumadoto (the $18^{\text {th }}-19^{\text {th }}$ centuries), were gathered by E.G. Filchakov in 1986, during archaeological reconnaissance on the Yamal Peninsula (Fig. 1).

\section{Materials and methods}

One male and three female skulls from the burials of the Buchta Nakhodka 2 burial ground, as well as one male and one female skull from Yumadoto 1 burial ground, were analyzed by

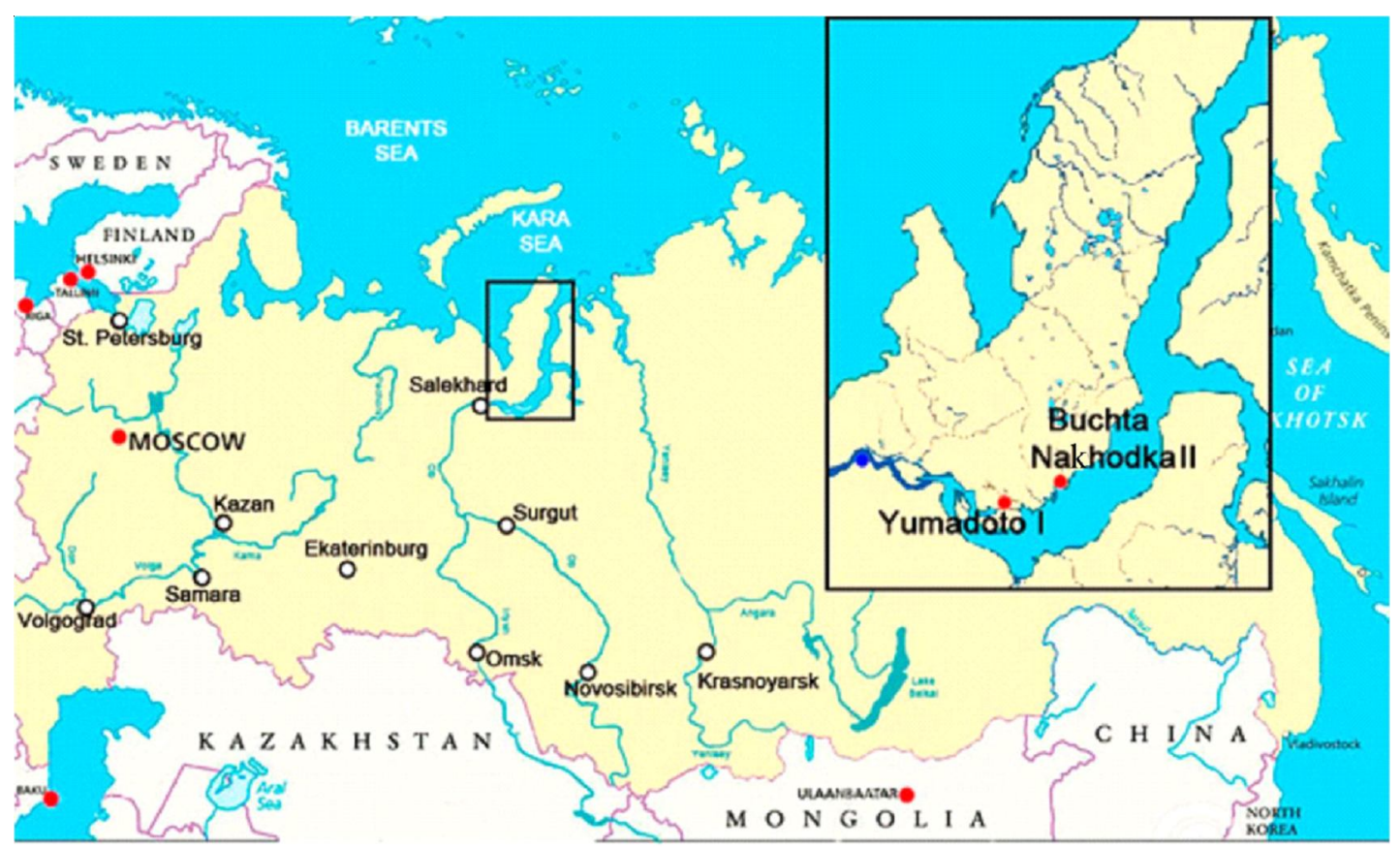

Fig. 1. Location of the burial grounds of Buchta Nakhodka 2 and Yumadoto 1 
means of craniology. Gender diagnostics was based on the morphology of a skull, lower jaw, pelvis and postcranial skeleton patterns $[6 ; 15$; 16]. The age of the buried was determined by the degree of obliteration of the skull seams and dental abrasion [6].

The skulls were measured using a standard craniometric technique supplemented by measuring the height of the forehead transverse flexion and calculating a conditional share of the Mongoloid element based on the index of the facial skeleton profile and the preauricul facio-cerebral index $[2 ; 11 ; 17]$. Inter-group similarity and differences were analyzed calculating the Mahalanobis-Rao D2 distance according to a program by Yu.K. Chistov (1994).

\section{Morphological features of the paleoanthropological findings}

The man's face is of medium width and height, it is moderately profiled in the horizontal plane at the middle level, but it is relatively more flattened at the orbital level. The size of the nasal part of the skull is average, the orbits are wide enough, with a low height. The facial skeletons of the female skulls are narrower and lower, flattened in the horizontal plane.

Disharmony can be observed in the structure of the male skull's nasal bridge. Its relatively large height is combined with a small width, while a very weak nasal bones protrusion over the line of the vertical profile of the face is observed. In the female group, small width and height in the nasal bridge structure are harmoniously combined with a relatively large nasal protrusion angle.

The male skull from Yumadoto I burial ground is characterized by a small value of longitudinal and transverse diameters (mesobrachicrania) while the cerebral cortex is of a very low height, a brachicranic form is typical of the female skull (Table 1).

Facial skeletons of the male and female skulls are similar in proportions and have an average width and height with a distinctly pronounced horizontal flattening. The structure of the orbits and of the nasal bridge is characterized by average values and proportions. Both skulls have a similar structure of the nasal bridge, its small width is combined with a small height along with a very small nasal protrusion angle.

In general, the morphological features of the studied skulls from the cemeteries of Buchta Nakhodka 2 and Yumadoto 1 indicate that they belong to an intermediate variant between the western and eastern anthropological formations. However, generalized indices of face flatness and proportions of the cerebral cortex show a predominance of elements in their craniological structure which bring the analyzed skulls closer to the Mongoloid populations (Table 1). A distinctive morphological feature of this group of skulls is a synthesis of the Mongoloid structure of the cerebral cortex with a horizontally flattened face and a small nose angle in combination with a relatively Europeoid structure of the nasal bridge, which is clearly expressed by the male skull from the burial site of Buchta Nakhodka 2. This disharmonic combination in terms of biological correlation is also observed in other West Siberian groups and, in general, there are reasons to support that according to the morphological characteristics the sample from Buchta Nakhodka 2 and Yumadoto 1 fits into the limits of variability of subarctic Siberian populations.

\section{Results of the analysis}

In order to specify general patterns of intergroup variability among the peoples of Northern Eurasia, their morphological features were analyzed using multidimensional statistics (canonical analysis). In order to stabilize the variability, craniological data on a number of ethnolinguistic communities were weighted and $=$ summed taking into account their geographical proximity. Thus, the male and female groups of the Ural anthropological type are generalized: the Northern Khanty (KhalasPogor burial ground [7]), a combined series from the Obdorsk vicinities and from the village of Muzhi [8]) and the Eastern Khanty (series from burial grounds of the Salym, Balyk, Vakh, Vasiugan Rivers Basins and from Urievo burial ground [9]). A series of skulls of the Northern Mansi collected in the $19^{\text {th }}$ century from various burial grounds in the Severnaya Sosva River Basin [7] was included among other populations of the Ural type. 
Mean values and indices for male and female skulls form the Northern Samodians

\begin{tabular}{|c|c|c|c|c|c|c|}
\hline \multirow{3}{*}{ Measurement } & \multicolumn{2}{|c|}{$\begin{array}{c}\text { Northern Samodians. } \\
\text { Total values }\end{array}$} & \multicolumn{2}{|c|}{ Yumadoto 1} & \multicolumn{2}{|c|}{ Buchta Nakhodka 2} \\
\hline & $\hat{\delta}$ & q & $\hat{\partial}$ & 운 & $\hat{\delta}$ & Q \\
\hline & $\bar{x}$ & $\bar{x}$ & $x$ & $x$ & $x$ & $\bar{x}$ \\
\hline 1. Cranial length, from $g$ & $178,9(21)$ & $172,3(24)$ & 174 & 169 & 189 & $167,5(4)$ \\
\hline 8. Maximum cranial breadth & $148,1(21)$ & $141,1(23)$ & 141 & 142 & 143 & $128,7(3)$ \\
\hline 17. Cranial height $(b a-b)$ & $128,8(20)$ & $122,8(23)$ & 123 & 128 & 125 & $113,7(3)$ \\
\hline 8:1. Cranial index & $82,9(21)$ & $81,9(19)$ & 81 & 84 & 76 & $78,1(3)$ \\
\hline 5. Cranial base length & $99,1(14)$ & $93,1(15)$ & 95 & 95 & 101 & $87,7(3)$ \\
\hline 9. Maximal frontal breadth & $94,1(20)$ & $91,3(23)$ & 96 & 97 & 88 & $88,3(3)$ \\
\hline 32. Forehead profile angle, from $n$ & $76,0(4)$ & $81,2(9)$ & 76 & 77 & 71 & $77,0(3)$ \\
\hline 40. Basion-prosthion length & $102,3(4)$ & $95,1(9)$ & 96 & 96 & 104 & $94,0(2)$ \\
\hline 45. Bizygomatic breadth & $138,3(13)$ & $130,1(13)$ & 134 & 130 & 136 & $120,3(3)$ \\
\hline 48. Nasion-alveolar height & $71,9(9)$ & $68,9(17)$ & 70 & 70 & 70 & $62,7(3)$ \\
\hline 72. General facial angle & $83,4(4)$ & $83,0(8)$ & 86 & 80 & 78 & $80,0(2)$ \\
\hline 77. Nasomalar angle & $148,6(4)$ & $150,9(11)$ & 145,2 & 151,4 & 147 & $151,4(3)$ \\
\hline$\angle$ zm'. Zygomaxillary angle & $134,4(4)$ & $135,6(8)$ & 132,7 & 130,5 & 131 & $136,2(2)$ \\
\hline 51. Orbital breadth, from $m f$. & $43,2(18)$ & $42,3(21)$ & 47 & 41 & 47 & $40,7(3)$ \\
\hline 52. Orbital height & $35,5(19)$ & $34,9(21)$ & 37 & 35 & 35 & $34,0(3)$ \\
\hline 55. Nasal height & $52,8(19)$ & $50,7(22)$ & 53 & 48 & 49 & $45,3(3)$ \\
\hline 54. Nasal breadth & $25,4(18)$ & $24,6(22)$ & 24 & 24 & 24,0 & $24,3(3)$ \\
\hline 75 (1). Nasal protrusion angle & $21,3(4)$ & $19,4(9)$ & 69 & 66 & 63 & $66,5(2)$ \\
\hline SC. Simotic chord & $6,6(4)$ & $6,4(11)$ & 4,0 & 6,7 & 8,0 & $5,6(3)$ \\
\hline SS. Simotic subtense & $3,0(4)$ & $2,3(11)$ & 2,1 & 2,9 & 3,5 & $2,2(3)$ \\
\hline DC. Dacrial chord & $19,7(4)$ & $18,2(11)$ & 20,5 & 19,3 & 18,0 & $17,5(3)$ \\
\hline DS. Dacrial subtense & $10,0(4)$ & $7,6(11)$ & 8,1 & 7,5 & 12,0 & $8,6(3)$ \\
\hline Index FSP & 77,5 & 84,6 & 86,0 & 85,8 & 73,9 & 75,3 \\
\hline PFC index & 97,0 & 97,4 & 95,5 & 94,2 & 98,7 & 86,4 \\
\hline CSME & 98,4 & 108,5 & 100,2 & 92,8 & 103,1 & 96,8 \\
\hline
\end{tabular}

Such samples of the Tomsk-Narym variant of the Ob-Irtysh anthropological type of the West Siberian formation as the Chulym Turks [20] and the Narym Selkups (series from the burial grounds of the Ob River Basin near Narym: Tiskino, Bederevskii Bor, Lukianovo and Maksimoiarsk, Barklay [5], a combined series from burial grounds at the entry of the Chulym River [10]).

As for the groups of the Yamalo-Yenisei anthropological type of the West Siberian formation, the data are grouped as follows: the Tundra Nenets [15], the Taz River Nenets [4] and a combined series on the Northern Samodyeds (the Nganasans [1], the Nadym Nenets [3], the Nenets of Yar-Sale and the Shchuch'ia River [8]). The Ket series is used according to the data of I.I. Gokhman and V.A. Dremov [12; 18].

The canonical analysis conducted in the body of populations under consideration clearly outlines the general patterns of intergroup variability.
Loadings on the characteristics of the first two vectors cover $57.5 \%$ of the total variance of the male samples, and $59.0 \%$ of the female samples, and notably, the factors of variability of the male and female materials for both vectors almost completely coincide. In both bodies, the greatest loadings for the $1^{\text {st }}$ canonical vector is accounted for by the series where skulls with a high cerebral cortex, but with a low facial skeleton, a weak protrusion of the nasal bones with a relatively higher nasal bridge predominate (Table 2 ).

The samples are differentiated according to their geographic location along the north-south line by this complex of features. Inhabitants of the southern regions of Western Siberia are moving away from their northern neighbors, the Ob Ugric people and the Northern Samoyeds. This observation confirms the fact noted by many researchers that there are elements of South Siberian genesis in the Narym Selkups and Chulym Turks (Fig. 1). 
Factor loadings

\begin{tabular}{|l|c|c|c|c|}
\hline \multirow{2}{*}{ Measurement } & \multicolumn{2}{|c|}{} & \multicolumn{2}{c|}{} \\
\cline { 2 - 5 } & $\begin{array}{c}\text { Canonical } \\
\text { vector I }\end{array}$ & $\begin{array}{c}\text { Canonical } \\
\text { vector II }\end{array}$ & $\begin{array}{c}\text { Canonical } \\
\text { vector I }\end{array}$ & $\begin{array}{c}\text { Canonical } \\
\text { vector II }\end{array}$ \\
\hline 1. Cranial length, from $g$ & -0.1647 & $\mathbf{- 0 . 4 4 8 2}$ & -0.2564 & $\mathbf{- 0 . 4 4 1 8}$ \\
\hline 8. Maximum cranial breadth & -0.0728 & $\mathbf{0 . 4 2 6 5}$ & 0.0800 & $\mathbf{0 . 3 5 3 5}$ \\
\hline 17. Cranial height $(b a-b)$ & $\mathbf{0 . 7 1 3 8}$ & $\mathbf{0 . 3 0 7 7}$ & $\mathbf{0 . 6 5 3 8}$ & 0.1491 \\
\hline 45. Bizygomatic breadth & 0.0609 & $\mathbf{0 . 3 4 0 2}$ & -0.0166 & $\mathbf{0 . 4 0 3 6}$ \\
\hline 48. Nasion-alveolar height & $\mathbf{- 0 . 3 4 8 8}$ & 0.2092 & $\mathbf{- 0 . 3 6 5 9}$ & 0.2613 \\
\hline 54. Nasal breadth & 0.2094 & -0.0172 & 0.1997 & -0.1887 \\
\hline 52. Orbital height & -0.1018 & -0.1761 & -0.1997 & 0.2003 \\
\hline 77. Nasomalar angle & -0.0983 & 0.1950 & -0.1136 & $\mathbf{0 . 5 2 7 8}$ \\
\hline Zzm'. Zygomaxillary angle & 0.0404 & 0.1101 & 0.0692 & -0.1477 \\
\hline DC. Dacrial chord & 0.1581 & 0.0810 & 0.2193 & 0.0203 \\
\hline DS. Dacrial subtense & 0.2507 & -0.1298 & 0.2047 & -0.1569 \\
\hline SS. Simotic subtense & 0.2011 & -0.0036 & 0.2606 & 0.1589 \\
\hline 75 (1). Angle of protrusion of the nose & $\mathbf{- 0 . 3 7 2 7}$ & $\mathbf{0 . 5 0 8 2}$ & $\mathbf{- 0 . 3 3 3 0}$ & 0.0076 \\
\hline Own value & 24.1 & 16.6 & 17.5 & 13.3 \\
\hline Percentage described variability & 34.1 & 23.4 & 33.5 & 25.5 \\
\hline
\end{tabular}

The complex of features of the $2^{\text {nd }}$ canonical vector differentiates the groups according to the shape of the cerebral cortex and the width of the facial skeleton. The maximum loadings fall at the most brachicranic skulls with a wide (eurimorphic) facial skeleton (naturally, regarding the materials under consideration), and the minimal loadings, at dolichocranic skulls with a narrow (leptomorphic) face structure. These features turned out to be taxonomically important, since they differentiate the Ural and the Yamalo-Yenisei groups by the degree of manifestation of dolichocrania and leptomorphism (Fig. 1).

The nature of interposition of the male and female groups in the correlation field of the $1^{\text {st }}$ and $2^{\text {nd }}$ canonical vectors indicates that the peculiarity of all West Siberian groups is a disharmonious combination of the Mongoloid complex (weak protrusion of the nasal bones, horizontally flat face and nasal bridge) with Europeoid features of the structure of the cerebral cortex (dolichocranic skull with a low face). But it is this combination of features which determines the anthropological specificity of West Siberian populations, especially of the Ural type, which serves as an indicator of their former racial and genetic unity. The same complex is typical of the Northern Samoyedic groups (but in a weaker form). The craniological type of the Kets is generally characterized by a combination of features typical of West Siberian groups, but having a number of features which bring them closer to the North Samoyedic samples (Fig. 1).

All Northern Samoyedic groups are distanced from a series of high-headed and low-faced skulls. This morphological feature is most clearly represented in the craniological structure of the $\mathrm{Ob}$ Irtysh populations of the West Siberian formation in the Narym Selkups and the Tomsk-Chulym Turks. At the same time, the Northern Samoyeds also deviate from more narrow-faced and dolichocranial samples. In our case, this feature is most clearly observed among the Ob Ugric people.

In general, inter-group variability in an aggregate of subarctic samples allows us to speak about the presence of certain morphological complexes in their composition: skulls with an elongated cerebral cortex and a small height have narrower and lower nasal bridges and faces more profiled in the middle part, combined with a small nose angle in relation to the vertical profile. The opposite situation is characteristic of brachicranic skulls, they have a face more or less flattened at the level of the orbits with a more protruding nose. The complexes of signs singled out are observed in a polarized form among the Ugric (dolichocraniality and related signs) and Nenets (brachicraniality and related characteristics) groups. Gravitation of the Northern Khanty to the Nenets is caused by the transgression of their areas, so that metisation processes between them could not but leave a trace in their gene pools. 


\section{АРХЕОЛОГИЯ}

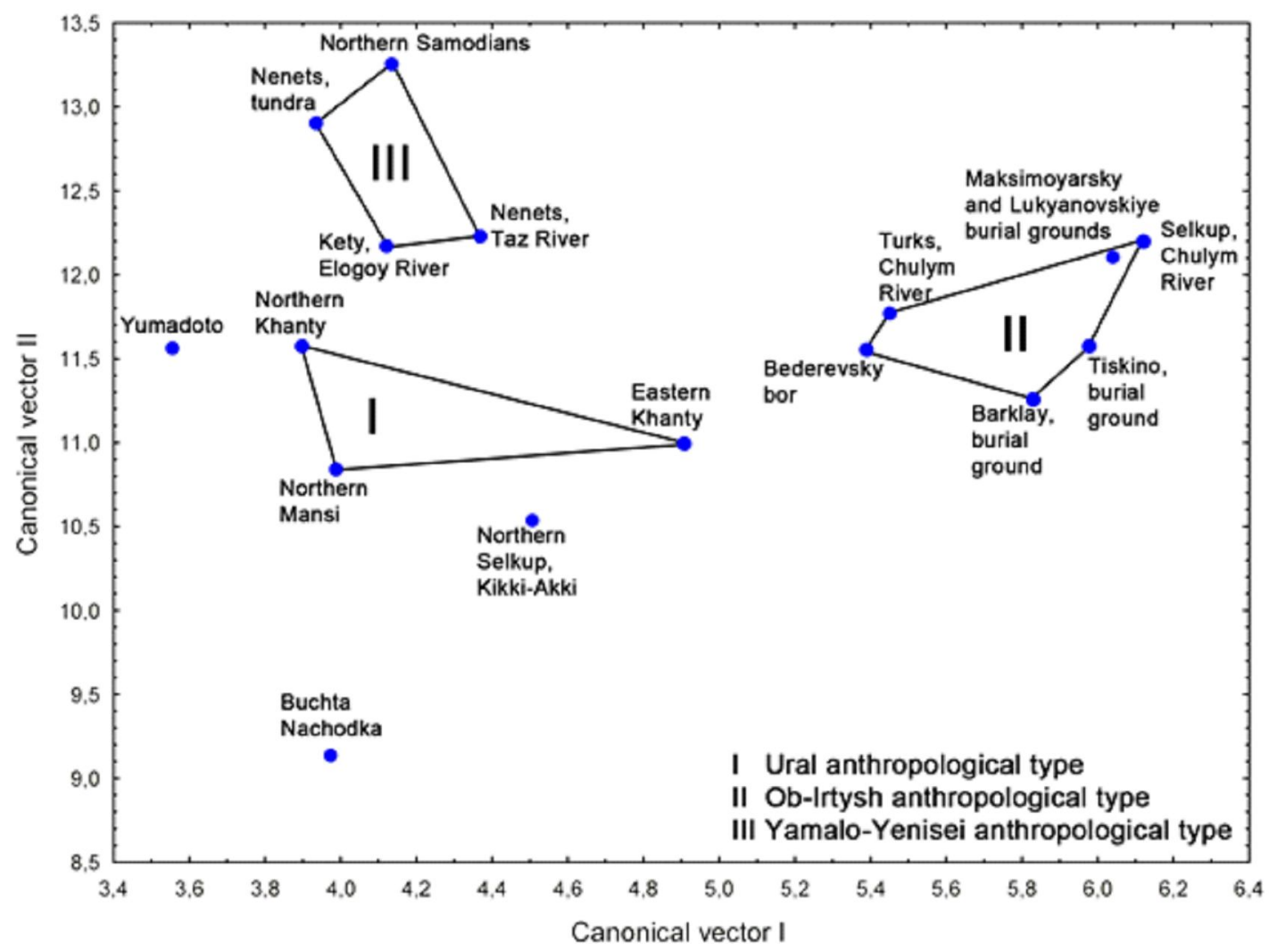

$a$

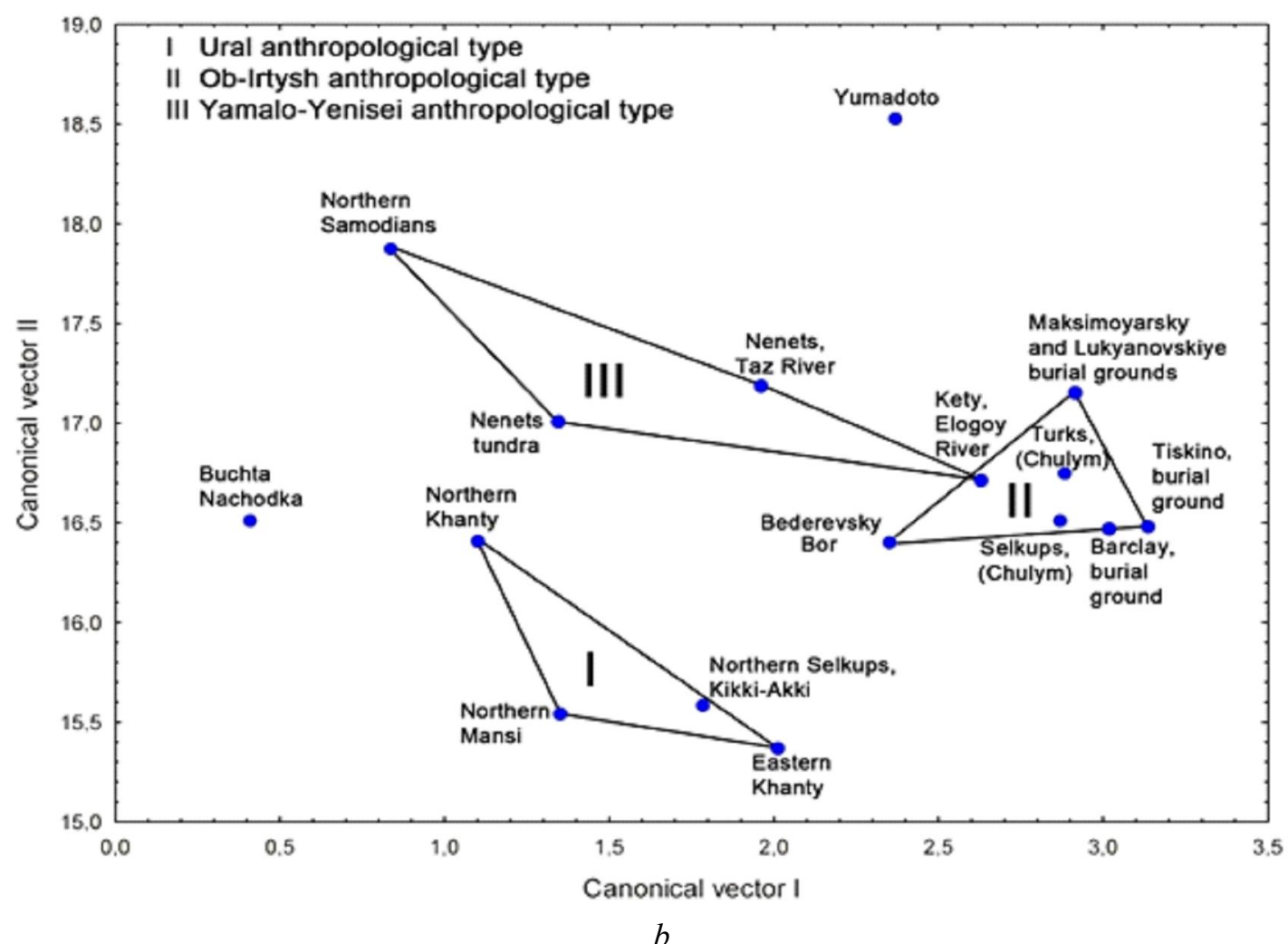

Fig. 2. Mutual location of the studied groups in correlational field of the $1^{\text {st }}$ and $2^{\text {nd }}$ vectors:

$$
a \text { - male groups; } b \text { - female groups }
$$




\section{Conclusion}

The studied anthropological materials from the burial grounds of Buchta Nakhodka 2 and Yumatodo 1 on the Yamal Peninsula made it possible to specify the limits of intra-group and inter-population variability of the Northern Samoyeds. Given the high individual variability of modern humans, the morphological features of the skulls from these burials and their location regarding other populations, we can certainly conclude that these skulls belong to the ethnolinguistic community of the Northern Samoyeds, which forms part of the YamaloYenisei anthropological type of the West Siberian anthropological formation. That is why it seems quite reasonable to include the group of skulls from the burial grounds of Buchta Nakhodka 2 and Yumatodo 1 into a selective/combined Northern Samoyedic sample, whose average characteristics are presented in Table 2.

\section{NOTE}

${ }^{1}$ The authors carried out this work within the research work plan of the Institute for North Exploration of the Tyumen Scientific Centre, Siberian Branch of the Russian Academy of Sciences, for 20182020, Minutes No. 2 of 8 December 2017. Priority direction XII.186; program XII.186.4; project number 0371-2018-0034.

\section{REFERENCES}

1. Alekseev V.P. K kraniologii nganasanov [On the Craniology of the Nganasans]. Kratkie soobshcheniya Instituta etnografii [Brief Reports of the Institute of Ethnography], 1955, iss. 24, pp. 7-65.

2. Alekseev V.P., Debets G.F. Kraniometriya: Metodika antropologicheskikh issledovaniy [Craniometry: The Method of Anthropological Research]. Moscow, Nauka Publ., 1964. 127 p.

3. Bagashev A.N., Razhev D.I. Nadymskiy gorodok. Paleoantropologicheskoe issledovanie [The Nadymsky Hillfort. Paleoanthropological Research]. Vestnik arkheologii, antropologii $i$ etnografii [Annals of Archaeology, Anthropology and Ethnography], 2009, vol. 11, pp. 11-24.

4. Bagashev A.N., Slepchenko S.M. Materialy po kraniologii tazovskikh nentsev [The Materials on the Craniology of the Nenets from the Taz River Region]. Chelovek i Sever: Antropologiya, arkheologiya, ekologiya [Man and the North: Anthropology, Archaeology and Ecology], 2015, vol. 3, pp. 6-10.

5. Bagashev A.N. Antropologiya Zapadnoy Sibiri [Anthropology of Western Siberia]. Novosibirsk, Nauka Publ., 2017. 406 p.

6. Buikstra J., Ubelaker D. Standards for Data Collection from Human Skeletal Remains. Arkansas, Arkansas Archaeological Survey Research, 1994. $202 \mathrm{p}$.

7. Debets G.F. Antropologicheskie issledovaniya $v$ Kamchatskoy oblasti [Anthropological Studies in the Kamchatka Region]. Moscow, Nauka Publ., 1951. $264 \mathrm{p}$.

8. Dremov V.A. Rasovaya differentsiatsiya ugorskikh i samodiyskikh grupp Zapadnoy Sibiri po dannym kraniologii [The Racial Differentiation of Ugric and Samoyed Groups of Western Siberia by Craniological Data]. Problemy antropologii drevnego i sovremennogo naseleniya severa Evrazii [Problems of Anthropology of the Ancient and Modern Population of the North of Eurasia]. Leningrad, Nauka Publ., 1984, pp. 106-132.

9. Dremov V.A. Kraniologiya sredneobskikh khantov [Craniology of the Middle Ob Khantys]. Obskie ugry: Khanty i mansi [Ob-Ugrians: Khanty and Mansi]. Moscow, IEA RAN, 1991, pp. 10-28.

10. Dremov V.A. Tomskie i chulymskie tyurki [Turks from the Region of Tom and Chulym Rivers]. Ocherki kulturogeneza korennogo naseleniya Zapadnoy Sibiri [Essays on Cultural Genesis of the Peoples of Western Siberia]. Tomsk, TSU Publ., 1998, vol. 4, pp. 67-84.

11. Gokhman I.I. Ugol poperechnogo izgiba lba i ego znachenie dlya rasovoy diagnostiki [The angle of Forehead's Lateral Bending and Its Significance for Racial Diagnosis]. Voprosi antropologii [Anthropological Issues], 1961, no. 8, pp. 88-98.

12. Gokhman I.I. Antropologicheskie aspekty ketskoy problemy: Rezultaty antropometricheskikh i kraniologicheskikh issledovaniy [Anthropological Aspects of the Ket Issue: Results of Anthropometric and Craniological Studies]. Ketskiy sbornik [Ket's Journal]. Leningrad, Nauka Publ., 1982, pp. 9-42.

13. Kardash O.V. Gorodok sikhirtya v Bukhte Nakhodka (pervye rezultaty issledovaniy) [The Sikhirtya Hillfort in Bukhta Nakhodka (Primary Research Results)]. Ekaterinburg; Nefteyugansk, AMB Publ., 2011.60 p.

14. Kardash O.V. Arkheologicheskie raskopki vyyavlennogo obyekta arkheologicheskogo naslediya "Mogilnik Bukhta Nakhodka 2》v Yamalskom rayone Yamalo-Nenetskogo avtonomnogo okruga $v 2016$ godu [Archaeological Excavations of the Discovered Object of Archaeolgical Legacy "The Burial Ground Bukhta Nakhodka 2" in 
the Yamal District of Yamalo-Nenets Autonomous Okrug in 2016]. Novosibirsk, 2016. 180 p.

15. LovejoyC.O. Dental wear in the Libben population: its functional pattern and role in the determination of adult skeletal age at death. American Journal of Physical Anthropology, 1985, no. 68, pp. 47-56.

16. Meindl R.S., Lovejoy C.O. Ectocranial suture closure: A revised method for the determination of skeletal age at death based on the lateralanterior sutures. American journal of physical anthropology, 1985, no. 68 (1), pp. 57-66.
17. Usolkina M.A. Provedenie arkheologicheskikh razvedochnykh rabot na poberezhye bukhty Nakhodka [Carrying out Archaeological Investigation Works on the Coast of Nakhodka Bay]. Ekaterinburg; Nefteyugansk, AMB Publ., 2012.95 p.

18. Zykov A.P. Barsova Gora: ocherki arkheologii Surgutskogo Priobya: Srednevekovye $i$ novoe vremya [Barsova Gora: Archaeological Essays on Surgut Ob Region. The Middle Ages and the New Time]. Ekaterinburg, Uralskiy rabochiy Publ., 2012. $232 \mathrm{p}$.

\section{Information about the Authors}

Anatoliy N. Bagashev, Doctor of Sciences (History), Director, Tyumen Scientific Centre, Siberian Branch of Russian Academy of Sciences, Malygina St., 86, 625003 Tyumen, Russian Federation, bagashev@mail.ru, https://orcid.org/0000-0003-2420-6276

Sergey M. Slepchenko, Researcher, Laboratory for Physical Anthropology, Tyumen Scientific Centre, Siberian Branch of Russian Academy of Sciences, Malygina St., 86, 625003 Tyumen, Russian Federation; Researcher, Ugra Laboratory for Archaeology and Ethnology, Surgut State University, Prosp. Lenina, 1, 628412 Surgut, Russian Federation, s_slepchenko@list.ru, http://orcid.org/0000-0002-93653849

Oleg V. Kardash, Candidate of Sciences (History), Senior Researcher, Ugra Laboratory for Archaeology and Ethnology, Surgut State University, Prosp. Lenina, 1, 628412 Surgut, Russian Federation, kov_ugansk@mail.ru, https://orcid.org/0000-0002-3331-7333

\section{Информация об авторах}

Анатолий Николаевич Багашев, доктор исторических наук, директор, Тюменский научный центр, Сибирское отделение РАН, ул. Малыгина, 86, 625003 г. Тюмень, Российская Федерация, bagashev@mail.ru, https://orcid.org/0000-0003-2420-6276

Сергей Михайлович Слепченко, научный сотрудник сектора физической антропологии, Тюменский научный центр, Сибирское отделение РАН, ул. Малыгина, 86, 625003 г. Тюмень, Российская Федерация; научный сотрудник Югорской лаборатории археологии и этнологии, Сургутский государственный университет, просп. Ленина, 1, 628412 г. Сургут, Российская Федерация, s_slepchenko@list.ru, http://orcid.org/0000-0002-9365-3849

Олег Викторович Кардаш, кандидат исторических наук, старший научный сотрудник Югорской лаборатории археологии и этнологии, Сургутский государственный университет, просп. Ленина, 1, 628412 г. Сургут, Российская Федерация, kov_ugansk@mail.ru, https://orcid.org/0000-0002$3331-7333$ 